\title{
Innovations in Information Systems for Business Functionality and Operations Management
}

\author{
Ruhul Amin \\ Senior Data Entry Control Operator (IT), ED-Maintenance Office, Bangladesh Bank (Head Office), \\ Dhaka, BANGLADESH
}

Copyright (C) 2014 (Ruhul Amin). This is an open access article distributed under the Creative Commons Attribution-NonCommercial-NoDerivatives 4.0 International License., which allowing others to download this work and share them with others as long as they credit us, but they can't change them in any way or use them commercially. In accordance of the Creative Commons Attribution License all Copyrights (C) 2014 are reserved for ABC Research Alert and the owner of the intellectual property (Ruhul Amin). All Copyright (C) 2014 are guarded by law and by $A B C$ Research Alert as a guardian.

\begin{abstract}
The industrial revolution brought about a smorgasbord of changes in the business environment. A lot of processes could be made more efficient, and productivity could be increased by a factor of a thousand. Nonetheless, after a century, the world's business sector experienced a period of relative stagnation. Later on, the technological revolution and the widespread use of information systems in business became a more significant disruptive force in the business world. Because of the rapid rate at which information technology evolves and is adapted for various applications, there are numerous opportunities to maximize functionality and productivity. The study covered topics such as computing and information technologies, decision analysis, nonlinear complementarity problems, optimization, revenue management, simulation, stochastic models, and stochastic optimization, among other things.
\end{abstract}

Keywords

İndustrial revolution, business environment, Information systems, Operations Management

\section{Introduction}

In an era characterized by revolutionary developments, basic information technology is the key to breaking barriers and bringing about more development. In its employment among organizations, innovation is increasingly critical to healthy competition, enterprises survival and business success. In the world of ventures, innovation is a significant response for meeting many challenges. Not only has it become the backbone of decision making, but also a means to create more business opportunities.

With information technology (IT), numerous processes have been automated, thus increasing productivity in the workplace (Ganapathy, 2018; Achar, 2018b). This is made possible through the leveraging of fewer resources, which enables the improvement of quality at lower costs. It also improves the speed with which ventures can deliver their services, which, in 
turn, makes it easier to reach even more clients. Through IT systems, we can store the same information and maintain its integrity.

Today, sensitive data and confidential information in a way that it is not prone to breach. The data can be recalled immediately when the need arises, and it can be analyzed to understand patterns or trends and attempt to predict the future. Because of this, IT innovations in information systems are relevant to enterprise decision making and business functionality.

\section{Review of Related Literature}

Insights into information systems have evolved so much that the needs of contemporary professional users have attracted substantial attention, especially in the research community. There have been developments in related fields, including information behavior, information seek, search and use. The attention to IT bringing competitive advantage is the reason for a false assumption that a company succeeds in the competition when it has more information.

On the contrary, too much information has the potential to hamper the efforts of the personnel trying to access, interpret and implement it. There's also the possibility of lavishing other resources in the process. The advancement in and the use of IT has made the acquisition and dissemination of data easier. However, at the same time, the advancement has heightened the risks associated with information overload. At the end line, a colossal amount of information can be handicapping to the essential functionality of a company and affect decision making.

Before a company can successfully leverage information, there needs to be a distinction between information (Achar, 2018a). As such, essential information needs to be made clear. The information required in making decisions need to be extensively defined. In the same way, the actions must be focused on acquiring this essential information. Since the 1920s (Lad Enterprises, 2008) information needs and the methods to obtain them have been discussed. Nevertheless, for a long time, the majority of the research has mostly brought librarians and other conventional information specialists into the spotlight.

Executive information systems (EIS) were first developed in the 1960s (Teswyn Hill, 2019), also immensely contributing to the expansion of research that define the information needs of businesses. The goal of business intelligence is making provision for error-free and timely venture information to aid decisions in operations and strategizing (Abbas, A.K.; Leonhardt, 2014). That means: business intelligence aims to satisfy the information needs of the data needs of managers. In doing so, it can enhance the organization's mode of operations and bring about reasonable competitive advantage (Ganapathy \& Neogy, 2017). However, defining the information is a cumbersome task and the methods employed need to be carefully selected in order for it to match the objectives and said case scenario.

When it comes to complex and dynamic business environments in the contemporary world, the various existing activities are responsible for the creation of the various information needs. Information needs can be described as the deliberate motive to utilize the data needed to support the people engaged in different kinds of activities. Information provides history, trends, insights and possible outcomes. Such comprehension of information needs is related to the definition of the data (Cohen, 2009). 
Information needs differ according to their number of features, levels of management, degree of formality, complexity, scope, urgency and the area of business or activities. In the area of decision support information needs, the primary interest of this paper is in the information systems as tailored for functionality in business. There are considerable research efforts in the field, but data for venture functionality is one of the most interesting and widely under-observed segments in information technology for industry.

The most significant disparity between business intelligence process models are found in the amount of phases, cycle structures and information sources, among other considerations (Pirttimäki and Hannula, 2003). Most of the innovative information system models talked about at the least phases are information need analysis, the acquisition of information, data change. Information distribution, and the final use for business operations and management. It is also conventional for the process models to function as an unending cycle, in order for the last phase of the process to culminate into the last, to complete and restart the cycle (C.S Fleisher, 2001).

The vitality of innovative information systems has witnessed a dramatic increase in the past decade, buoyed by a continuously increasing number of businesses that have implemented them for operations and management. (Davidavičienè, 2008). The modern day organization cannot be managed in the absence of an efficient information system (Achar, 2016). Subsequent to a litany of research, stones were not left unturned as to the reality that the implementation of an information system in an organization can bring about many upsides in dealing with internal and external operations. It helps with tasks that a company might face in its day to day operations (Paruchuri, 2017).

Continuous innovations have not only resulted in amplified performance on hardware and software, reduced costs and offered a greater platform for data-driven businesses, but also became another chief factor in the promotion of the widespread adoption of computerized systems across the planet.

\section{Research Methodology}

Business operations and management functions are being reshaped by innovation systems. As such, this paper used the systematic literature review (SLR) methodology to determine the degree to which information system and management-related research remains underdeveloped in the research of today. First off, the SLR was used to develop a comprehensive protocol to streamline the activities. The essence of this protocol is to reduce the odds of arriving at biased results (Paruchuri, 2015). The paper is concretized by highlighting an approach and set of conditions to maximize quality measures. Our protocol specifies the question the paper attempts to ask, the academic databases where information is sourced from, and the search terms. It also specifies the inclusion and exclusion criteria for sifting through the considered studies. After the process, the research papers were categorized into information systems-related, management-related and functionality-related studies.

This arrangement was designed to help gain a thorough understanding of how IT systems operate in the business environment and the impact they have on venture operations as well as management. At the onset, the search terms and keywords in direct association with the information systems domain were selected to include emerging disruptive technologies, ap- 
proaches and paradigms (Achar, 2015). Later on, the nodes were designed in Nvivo 12 and transformed into thematic depictions.

At the final stage's paper's agenda was identified along these themes and linked to business process management trends to enable a more structured scope of the SLR outcomes. An expert panel study (Van Looy and Poels) was conducted to formulate and link the trends to information systems-related managerial strategies. Nonetheless, the authors called for a more conceptual approach that can supplement their future trends with literature. This is to help better position the chasm between what is already known and what needs to be known, from practice. In this missing angle lies the purpose of our SLR.

\section{Information Systems and Business Performance}

According to research (Awais et al, 2012), over the past few decades, companies across the world began to take note of the considerable need of information systems in the field of business. It has become hardly possible to neglect the many benefits of data availability, as well as the possibility to amplify business performance through such an investment. The research quickly observed that an information system is capable of enabling a business to save money, increase their competitive hold and better operational performance (Vadlamudi, 2015). At the end of it, more profit is created for the venture.

In today's world, increasing business performance by innovating information technology solutions is common. An increase in business performance can be expressed as the intermediate stage between an IT system and business-focused strategy. Figure 1 is used to demonstrate the structure of business performance, the one which lies between IT-assisted business operations and functionality. The figure suggests that the functionality (which can also be called the performance) of a business can be intensified through information systems. In different words, IT systems impact performance to achieve company goals.

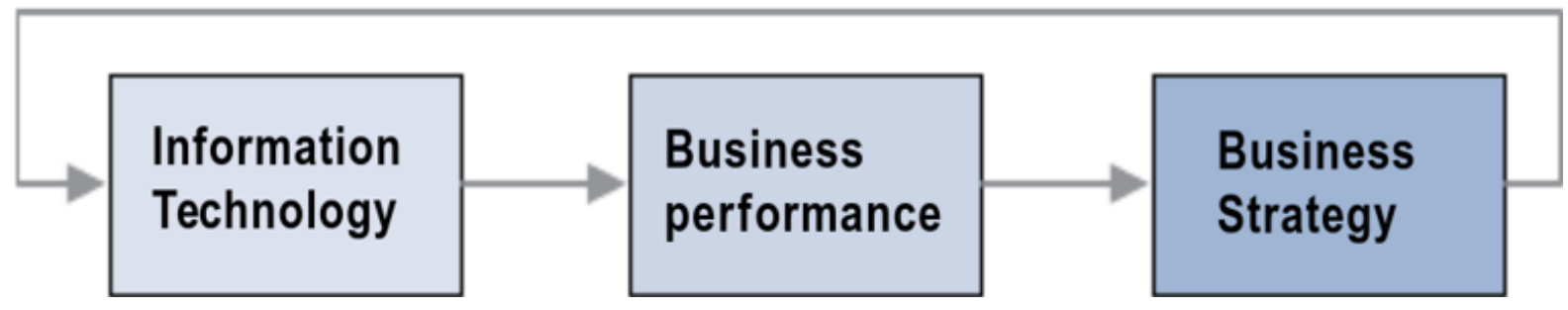

Another paper (Sward, 2006) supports the conclusion, which suggests that performance is the end product of some of the benefits brought to different business units and the organization as a whole, thanks to information systems expressed in various parameters. The entire improvements in IT systems can result in lower costs and make activities more worthwhile. The solutions improve the monitoring and coordination within a business (Hendershott, 2006).

Consequently, it is statable that the general impact of IT on business functionality can be denied by the analysis of the tangible and intangible benefits that were realized after implementing the data derived from an information. This is more often than not an economic drawback for various types of business investments, not necessarily information systems alone (Paruchuri, 2018). Commonly, this becomes an issue as a result of the complexity of 
evaluating investment effects on a business' operational performance and functionality. Such effects should be first understood and later manically calculated (Silvius, 2006).

Investing in the fashioning and application of information systems is of exceptional importance to strategizing for venture as it also improves the quality of the services rendered (Vadlamudi, 2018). To have a more encompassing understanding of innovative IT systems' impact on business functionality, the definition, entailments and classes of data systems are first determined.

\section{Types of Information Systems}

Information systems can be referred to as a set of components designed to aid the collection and sharing of information and data via software, hardware, core ware and organ ware. Such systems are the basic principles for the financial developments of a business, whether small, mid-sized or large (Nikjoo et al., 2011.

Another definition (Awais et al., 2012) says information systems can be described as an amalgamation of technological and human resources to perform actions in bid to bolster business activities. It can also be called the application landscape. Information systems can also be used to describe how users, algorithmic processes, information and technology interact. They can also be understood as semi-formal language platforms that enable improved decision making.

The definitions for information systems might be numerous, but, in all cases, these systems are grouped into five categories. The categories are depicted in Figure 2 (Molla, Heeks 2003; Nowduri 2010; Awais et al. 2012; Reddy et al. 2009; Chichernea 2009)

- Office Information Systems (OIS).

- Transaction Processing Systems (TPS).

- Management Information Systems (MIS).

- Decision Support Systems (DSS).

- Executive Support Systems (ES).

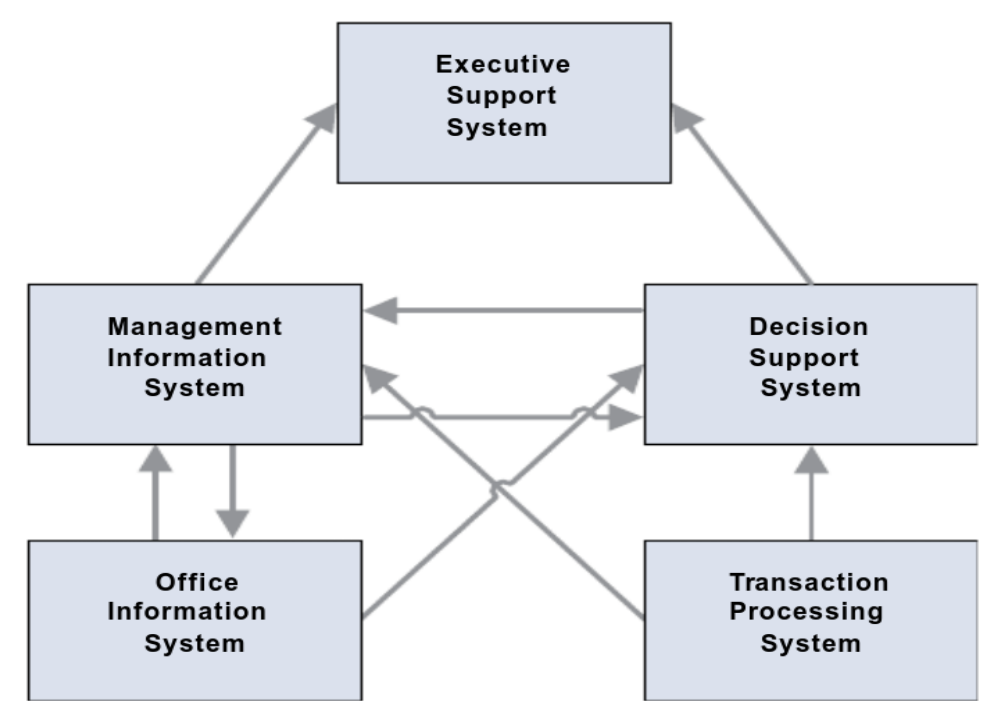


These system groups are interrelated when it concerns the flow of data and information. The arrows show the direction through which information is transferred from one system to another. The diagram is also a representation of the object of analysis in each category. The executive support systems receive information from management information systems and decision support systems.

Management information systems use data from office information systems, transaction processing systems and decision support systems. The decision support systems, in turn, use data from management information systems, transaction processing systems and office information platforms. The office information systems are then blocked by management information systems (Vadlamudi, 2017). The only systems in the network serving as the providers (not the consumers) are the transaction process systems.

As regards the purpose, functionality and operational possibilities of the aforementioned systems, there are different descriptions suggested in a variety of scientific courses. Of all explanations, the most relevant of every system is provided to acquire a more robust comprehension of the said information systems. The influence on the improvement of business performance is also considered (Paruchuri \& Asadullah, 2018).

An office Information System (also known as OIS), is an information system which is designed to enhance in-business processes and make communication between different users easier, This is acheived by integrated software, hardware and series of networks. Leveraging the digital power of computers, and other electronic devices, employees will be able to perform the majority of their tasks automatically, as opposed to manually completing them (Awais et al, 2012).

A Transaction Processing System (TPS) on another hand, is an information system which collects, preserves and processes information on a daily basis, for the sake of semales transactions (Molla and Heeks, 2003). With these systems, the routine questions of business operations and functionality can be answered. A Management Information System (MIS), then, is an information system that is concerned with collecting, processing, storing and transmitting import business data in order to assist managers in performing their tasks.

Management Information Systems provide relevant, timely and actionable information, which is then used in the decision making stage. Ultimately, these units help managers to plan and control more efficient business operations. A Decision Supporting System (DSS) in an information system which enables its users to analyze the information. Helpful for their business needs, the data is presented in a way that it will suitably lend a hand in decision making. By this means, decisions are made more efficiently. An Executive Support System (ESS) is an information system whose main use case is as a reporting software, which helps to transform business-related data into summaries and reports. Much of these reports are used by venture executive managers for short and long-term scheduling/planning.

Because every of these systems are meant to cover specific areas in business - and support equally specific business processes - it is advisable to have the systems integrated and interconnected into one system of information, one that would be able to meet the business needs as per relevant operations. A typical example of an integrated information system is an enterprise resource planning system. Enterprise resources planning systems (ERPS) are considered 
to be one of the best business information technology solutions ever to have graced the last few decades (Framinam, 2008). This is so because most small to mid-sized and large enterprises can as well benefit from them.

ERPS are also systems designed to process information and enterprise transactions, and foster the integrated production, planning and customer feedback (Chung and Skibniewski, 2007). They are analyzed to be a combination of all the systems operating in the different departments of a company. It is referred to as a single but heavily-packed integrated program which runs one database in a manner which enables different company departments and business units to share information freely and easily communicate with one another. Within a venture, optimizing of information and resources utilized by different units can be achieved only if the systems are interconnected. In fact, it is helped to be the topmost priority in enterprise resource planning systems (Nikjoo et al., 2011).

It has been concluded that enterprise resource planning systems are fully integrated and account for all areas and activities within the venture. They consist of several modules, including financials, accounting, human resource (HR) management, sales and distribution marketing, planning, advertising, quality management, purchasing management and material management (Merkuryev and Tambovcevs, 2009).

\section{ERP Implementation and Business Performance}

Unarguably, the enterprise resource planning implementation can lead to productivity and turbocharge efficiency at the workplace. IMproved performance can be achieved via a variety of benefits, some of which can be seen early and evaluated or just based on assumptions (Bingi et al., 1999 Cronin et al. 1994; Koushik, Pete 2000). Case in point, numerous competitive advantages come out from ERPS, including the reducing of business costs, quick customer support and the acceleration of corporation connections.

Enterprise resource planning systems help to simplify work processes, hasten corporate responses and amplify the validity and timeless of the information provided. Also, it reduces the secretarial work process to the barest minimum. ERPS can as well be used in the improvement of the output sales value and lower the inventory turnover rate of a business (Dykeman, 1997).

When the value chain of the Internet is applied to marketing and brand-related research, enterprise resource planning systems can also effectively increase the market share of an enterprise. In the process, it will reduce the marginal costs and boost customer satisfaction (Cronin et al, 1994). All the benefits of ERPS are classified (Tsaia et al., 2011) into two categories so that all the effects can contribute to the general functionality of a business.

There are two main indicators that can explain the way business performance changes after innovative information systems have been implemented. Namely, performance of internal processes and the improvement in the company's financial performance. In essence, performance of internal processes is the simplification of the company's international process and the improvement of its database (Tsaia et al., 2011). 


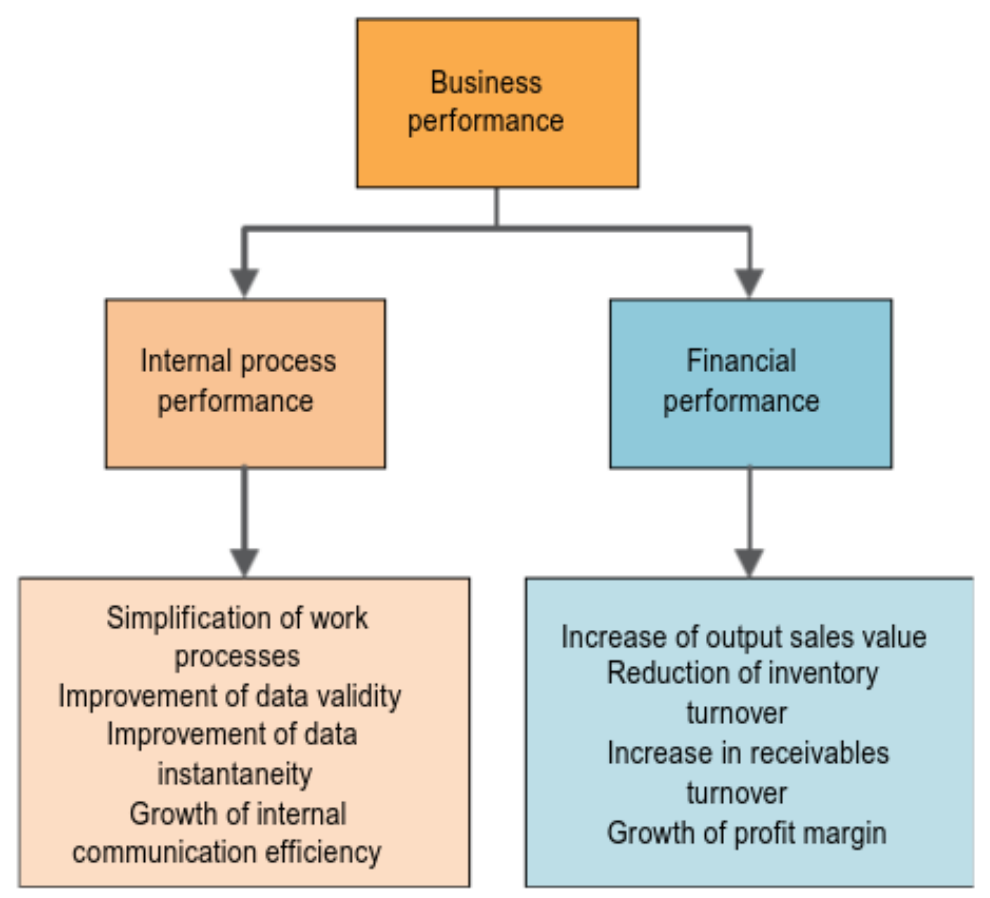

The potential benefits that await performance when enterprise resource planning systems have been implemented are enormous, possibly varying from improved information management to lower operational costs (Davenport, 2000). Notably, the entirety of those upsides are not immediately manifested or with the purchase/installment of an information system. The benefits might become visible only when the enterprise starts to effectively use bought or created IT assets (Soh and Markus, 1995). The process can be long-term and demands a great deal of resources: money, skills, and time.

\section{Management Information Systems}

Information systems are well supported on the evolutionary continuum of innovation (Sprague, 1980; Kendall, 1982; Shim, 2002; Power, 2007). However, the exactness of the location of a specific system remains a debate. The natural location. There is an approach to classifying information systems innovations from databanks, where everything is stored into a decision-making unit that initiates the action of the system (Mason 1969; Vadlamudi, 2016).

Management Information Systems, in a different paper (Ackoff, 1967) as posited as innovations from control systems. This suggests that information systems are subsystems of control systems. Electronic Data Processing (EDP) is the genesis of these systems, all of which are supposedly focused on data availability.

When such a focus is transferred to information, they become management information systems. As that focus turns towards the management side, the term Decision Support System was initiated. According to Sprague (Sprague, 1980), differing views of systems progressions are considered as natural evolutionary advancement to newer systems. These newer systems are subsets of previous generations to them. 
Management Information Systems are an extension of data processing systems where provision of standardized reporting is emphasized above the translation of transactions into records as per automation of data processing systems (Ganapathy, 2017).

\section{Observations and Conclusion}

Dwelling on the analysis on the theoretical ramifications regarding how information systems have influenced business functionality and operations managements, we have come to a handful of conclusions.

First off is that the growing need for data in today's industry and general world demands the development of credible innovative information systems. As such, every business, regardless of size, industry or ten-year goal, needs to keep tabs with the latest advancements in the information technology field to adopt technological solutions for business management.

One of the information innovations that improve the efficiency of a venture is information systems, which play a critical role in the business life of today. The systems improve their goals, targets and overall strategies.

In the current days, an increasing number of enterprises have invested money into innovative information systems so they can improve business performance. By investing in and innovating information systems, businesses can transport operational processes to achieve higher efficiency. The production process, customer service and accounting can be better.

We also found that information systems, when innovated, can help in the identification of the existing issues and loopholes in a company's flow. They have the potential to bring a lot of benefits, which in turn increases the financial wellness of a company.

It is arguable that all but the primordial, data-processing focused MIS are describable as DSS. Indeed, (Gorry and Scott-Morton, 1971) assert that "information systems should only exist to support decisions". Information only has meaning in the context of a decision (Nichols, 1969) and many authors speak of management decisions with reference to MIS (Laudon and Laudon (2002); Keen (1980); Nichols (1969).

The point where DSS are distinguishable from MIS is notable. Whereas MIS may indeed support management decision making, MIS are not described as analytical. Once analyses are introduced, especially when modelling aids in that analysis thenceforth a DSS is born. An MIS is missing attributes required for a decision support system (Sprague \& Watson, 1996). They specifically refer to innovations such as "analytic aids" as necessary for a system to be describable as decision support.

\section{References}

Abbas, A.K.; Leonhardt, S. Intelligent neonatal monitoring based on a virtual thermal sensor. BMC Med. Imaging 2014, 14, 9.

Achar, S. (2015). Requirement of Cloud Analytics and Distributed Cloud Computing: An Initial Overview. International Journal of Reciprocal Symmetry and Physical Sciences, 2, 12-18. Retrieved from https://upright.pub/index.php/ijrsps/article/view/70 
Achar, S. (2016). Software as a Service (SaaS) as Cloud Computing: Security and Risk vs. Technological Complexity. Engineering International, 4(2), 79-88. https://doi.org/10.18034/ei.v4i2.633

Achar, S. (2018a). Data Privacy-Preservation: A Method of Machine Learning. ABC Journal of Advanced Research, 7(2), 123-129. https://doi.org/10.18034/abcjar.v7i2.654

Achar, S. (2018b). Security of Accounting Data in Cloud Computing: A Conceptual Review. Asian Accounting and Auditing Advancement, 9(1), 60-72. https://4ajournal.com/article/view/70

Ackoff, R. L. (1967). "Management Misinformation Systems." Management Science 14(4): pB-147-B-156.

Awais, M.; Irfan, M.; Bidal, M.; Samin, T. 2012. Helpful Business Value of Advance BAL Information System, IJCSI International Journal of Computer Science Issues 9(2): 415-422. ISSN 1694-0814.

Bingi, P.; Sharma, M. K.; Godla, J. K. 1999. Critical issues affecting an ERP implementation, Information Systems Management 16(3): 7-14.

C. S. Fleisher, "An Introduction to the Management and Practice of CI" In: C. S. Fleisher \& D. L. Blenkhorn (eds.), Managing Frontiers in Competitive Intelligence, Quorum Books, Westport, 2001.

Chung, B.; Skibniewski, M. 2007. Cost-Benefit analysis of ERP Modules in Construction Firms, in Proceedings of the ASCE/CIB Construction Research Congress. Newport, Bahamas, 1-10.

Cronin, B.; Overfelt, K.; Fouchereaus, K.; Manzvanzvike, T.; Cha, M.; Sona, E. 1994. The internet and competitive intel-ligence: A survey of current practice, International Journal of Information Management 14(3): 222-240.

Davenport, T. H. 2000. Mission critical: realizing the promise of enterprise systems. Harvard Business School Press, Boston, MA. ISBN 0-87584-906-7.

Davidavičienè, V. 2008. Change management decisions in the information age, Journal of Business Economics and Management 9(4): 299-307.

Dykeman, J. 1997. EDI moves toward the Internet, Managing Office Technology 42(6): 37.

Framinan, J. M. 2008. Book review, International Journal of Production Research 46(1): 297-298.

Ganapathy, A. (2017). Friendly URLs in the CMS and Power of Global Ranking with Crawlers with Added Security. Engineering International, 5(2), 87-96. https://doi.org/10.18034/ei.v5i2.541

Ganapathy, A. (2018). Cascading Cache Layer in Content Management System. Asian Business Review, 8(3), 177-182. https://doi.org/10.18034/abr.v8i3.542

Ganapathy, A., \& Neogy, T. K. (2017). Artificial Intelligence Price Emulator: A Study on Cryptocurrency. Global Disclosure of Economics and Business, 6(2), 115-122. https://doi.org/10.18034/gdeb.v6i2.558

Gill, T. G., \& Cohen, E. (Eds.). (2009). Foundations of informing science: 1999-2008. Santa Rosa, CA:

Gorry, G. A. and M. S. S. Morton (1971). "Framework for Management Information Systems." Sloan Management Review 13(1): 55-70.

Lad Enterprises, Inc., View of Information Technology's Relationship to Business, www.ladenterprizes.com, June 2008.

Laudon, K. C. and J. P. Laudon (2002). Management information systems: managing the digital firm. Upper Saddle River, N.J. London, Prentice Hall: Prentice-Hall International. 
M. Hannula and V. Pirttimäki, "A Cube of Business Information”, in Journal of Competitive Intelligence and Management, Vol. 3, No. 1, 2005, pp. 34-40.

Mason, R. (1969). "Basic Concepts for Designing Management Information Systems." AIS Research Paper No. 8.

Merkuryev, Y.; Tambovcevs, A. 2009. Analysis of ERP systems implementation in the construction enterprises, Computer Science 40: 16.

Molla, A.; Heeks, R. 2003. Management and Organizations Support Information Systems. IDPM, University of Manchester.

Nichols, G. E. (1969). "On The Nature of Management Information." Management Accounting 15: 9-13.

Nikjoo, M. A.; Khan, M. M.; Moghimi, A. 2011. Fuzzy TOPSIS and GP Application for Evaluation and Selection of a Suitable ERP, Australian Journal of Basic and Applied Sciences 5(11): 1358-1367.

Paruchuri, H. (2015). Application of Artificial Neural Network to ANPR: An Overview. ABC Journal of Advanced Research, 4(2), 143-152. https://doi.org/10.18034/abcjar.v4i2.549

Paruchuri, H. (2017). Credit Card Fraud Detection using Machine Learning: A Systematic Literature Review. ABC Journal of Advanced Research,6(2), 113-120. https://doi.org/10.18034/abcjar.v6i2.547

Paruchuri, H. (2018). AI Health Check Monitoring and Managing Content Up and Data in CMS World. Malaysian Journal of Medical and Biological Research, 5(2), 141-146. https://doi.org/10.18034/mjmbr.v5i2.554

Paruchuri, H., \& Asadullah, A. (2018). The Effect of Emotional Intelligence on the Diversity Climate and Innovation Capabilities. Asia Pacific Journal of Energy and Environment, 5(2), 91-96. https://doi.org/10.18034/apjee.v5i2.561

Soh, C.; Markus, L. 1995. How IT creates business value: a process theory synthesis, in Proceedings of the 16th Annual International Conference on Information Systems, 29-41. Amsterdam, The Netherlands.

Sprague, R. H. and H. J. Watson (1996). Decision support for management. Upper Saddle River, N.J., Prentice-Hall.

Sprague, R., \& Carlson, E. (1982). Building effective decision support systems. Englewood Cliffs, NJ:

Tsaia, M.-T.; Lib, E. Y.; Leec, K.-W.; Tunga, W.-H. 2011. Beyond ERP implementation, the moderating effect of knowledge management on business performance. Total quality man-agement \& business excellence: an official journal of the European Society for Organisational Excellence 22: 131-144. Abingdon, Oxfordshire, UK. ZDB-ID 21017797.

Vadlamudi, S. (2015). Enabling Trustworthiness in Artificial Intelligence - A Detailed Discussion. Engineering International, 3(2), 105-114. https://doi.org/10.18034/ei.v3i2.519

Vadlamudi, S. (2016). What Impact does Internet of Things have on Project Management in Project based Firms?.Asian Business Review, 6(3), 179-186. https://doi.org/10.18034/abr.v6i3.520

Vadlamudi, S. (2017). Stock Market Prediction using Machine Learning: A Systematic Literature Review. American Journal of Trade and Policy, 4(3), 123-128. https://doi.org/10.18034/ajtp.v4i3.521

Vadlamudi, S. (2018). Agri-Food System and Artificial Intelligence: Reconsidering Imperishability. Asian Journal of Applied Science and Engineering, 7(1), 33-42. Retrieved from https://journals.abc.us.org/index.php/ajase/article/view/1192 